\title{
The Pleistocene History of the West Midlands*
}

\author{
By Prof. Leonard J. Wills
}

\section{The Different Types of Drift aNd TheIR Distribution}

$\mathrm{T}^{\mathrm{n}}$ HE region I propose to deal with is bounded on the west by the north-south line of hills from the Clees in Shropshire to Malvern; on the south by the Cotteswold escarpment; and on the east by the watershed surrounding the headwaters of the Avon. Its northern limit may be defined by a line from Iron Bridge to Wolverhampton, Lichfield, 'Tamworth, Nuneaton, Rugby. Within these boundaries there are the two great vales of Severn and Avon, embracing on the west, south and east a triangular plateau drained by the Cole, Blythe and Tame, which carry its waters away northwards to the Trent. In this 'Midland Plateau' is the high ground of the South Staffordshire coalfield reaching, via the Lickey Hills, into East Worcestershire and West Warwickshire, and into the high ground of the East Warwickshire coalfield : the lower ground of the Cole and Blythe valleys between these heights is itself elevatedan upland rather than a vale.

The greatest anomaly in the topography is the valley of the Severn, which is cut, first as a gorge, through what should be a major watershed at Tron Bridge, and later as a sort of groove along the west side of the great vale-like depression the centre line of which lies a few miles to the east. It is probable that in pre-Glacial times the upper Severn went to the Irish Sea, that the watershed of England separated it at Iron Bridge from the middle and lower Severn, which then had its source where now the Worfe rises. From here it may have followed the line of the great depression now occupied by the valleys of the Worfe and Claverley Brook, the Lower Stour, the Elmley Brook and Salwarpe, and the Bow and Piddle Brooks.

A thorough appreciation of the vast extent to which erosion has gone on, and of the enormous length of time involved, at once helps us to understand the apparently anomalous distribution of Glacial drifts in this region, in which, as a rule, the vales and lower ground are free from Glacial deposits, whereas the higher country and the watershed areas are extensively and often heavily drift-covered-a disposition that is the exact converse of the usual arrangement in a glaciated region. I shall attempt to show in the sequel that

* From the presidential address to Section C (Geology) of the British Association, delivered at Nottingham on September 3. the drifts formerly extended beyond the regions where they now form large outcrops, and that their absence from an area need not be taken as an indication that it was never under ice.

The drift-covered areas may be grouped in relation to the major watersheds, as follows:

(1) Watershed between the Tern and Penk on the north and the Severn, Worfe and Smestow on the south, and between the Penk and the Shenstone Brook. Towards the north-west it is continuous with the heavily drift-covered plain of North Shropshire.

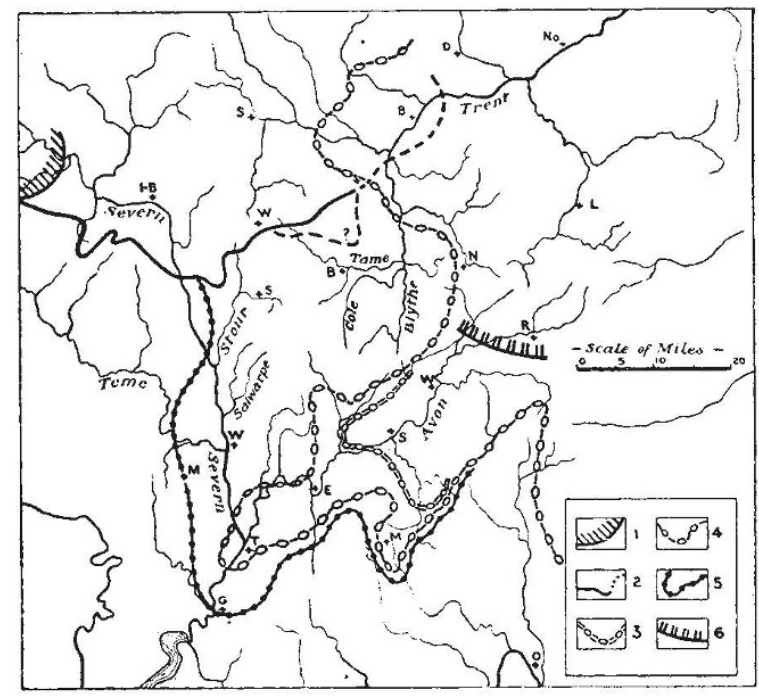

Fig. 1.

THE SPHERES OF INFLUENCE OF THE GLACIERS THAT INVADED THE MIDLANDS. 1, LitTtLe WELSH GLACIER OR 'Welsh Re-Advance' ; 2, MaIn Irish Sea glacter ; 3 , Stratford STAGE OF, and 4, SUPPOSED MAXIMUM of Great Eastern glacier ; 5, Maximum of Frrst WELSH GLACIER; 6, POSSIBLE SOUTHERN LMMITS OF A VERY EARLY EASTERN GLACIER.

(2) Watershed between the Tame on the north and the Penk, Severn and Avon. This contains most of the Midland Plateau, as defined above.

(3) The watersheds between the Avon, Anker and Soar.

Each of these three areas is characterized by a particular type of drift (Fig. 1). Yet each type is by no means confined to one district, but as a rule has had a wider distribution, evidence for which may in some cases be found in the intervening vales.

In the first or north-westerly district the drifts belong, perhaps exclusively, to the Main Irish Sea 
glaciation. They are full of Scottish and Lake District erratics, and contain fragments of shells picked up from the floor of the Irish Sea. In addition, there is material from Wales; but this, for the most part, has probably been incorporated from the deposits of earlier glaciations. There seems very little evidence of such older deposits still in their original positions.

The Irish Sea glacier advanced inland counter to the drainage, and in our district surmounted the watershed. It is significant that its deposits occur on the watersheds and at the same time reach into the valleys. The southern limit of the Main Irish Sea drifts is shown on Fig. 1. It is generally marked by a great concentration of boulders.

It is now generally accepted that we can divide our British Glacial deposits into 'Older' and 'Newer Drifts'. The Newer can be recognized by reason of the freshness and unaltered state of their surface features, which exhibit clearly original forms like kames, åsar, kettle-moraine, moraine-lakes, and so on. Their obvious influence on, and relation to, the present drainage is another characteristic feature. On both these counts, the Irish Sea Drifts of this north-western area must be regarded as part of the Newer Drifts. Outside the line marking their limits the rest of the Midlands belongs to the realm of the Older series, and has remained extraglacial since the time of the deposition of the latter.

It is fortunate that the Irish Sea Glacier brought with it a great influx of Scottish and Lake District erratics, for such vast numbers of them found their way into the Severn via the Worfe and Smestow as to give a characteristic lithology to the Main and Worcester Terraces, by which they can be recognized with certainty as later than the terraces which belong to the time of the 'Older Drifts'.

The other two districts belong to the domain of the 'Older Drifts'.

We may consider next the eastern area. Here the most characteristic drift is the Chalky Boulder Clay and its associated flinty gravels and sands. Though there are other drifts present, these deposits are proved by superposition to be the most recent. As is well known, the Chalky Boulder Clay was the product of a mighty ice sheet to which Harmer gave the title of the Great Eastern Glacier, the limits of which are indicated on Fig. 1. In the main area, which is that lying east of the Tame and lower Anker, and round Nuneaton, Coventry and Rugby, the drifts are the westward continuation of the great spreads of Rutland and Northamptonshire so clearly delineated on Harmer's famous map of English erratics. From the Soar and Anker valleys there is an extension into the Trent valley. Southwards, the 'Main Eastern' drifts (of Miss Tomlinson) near Stratford-onAvon appear also to belong to the Chalky Boulder Clay Series. The same is true of the 'Moreton Drift' of the same author, though this can only be linked with those of Stratford by a series of hill-top occurrences in the otherwise drift-free vale of Avon.

In the last of our three drift-covered areas, the Midland Plateau, it is not easy to generalize about the distribution, composition and origin of the drifts. Often they consist of 10-20 feet of pebbly clay, sands and coarse gravel, but there are several districts where far thicker deposits occur. Most of the Warwickshire Plateau has a covering of clayey gravel, sand and sometimes coarse gravel. The high-level drifts of the Ridgeway and of the hill-tops of Worcestershire are chiefly sands and gravels, 'fringe' deposits as Jerome Harrison termed them, implying that they were mainly periglacial in origin. On the Ridgeway there are also areas of clayey ground-moraine.

The composition of the drifts varies somewhat, but they always include a great deal of Bunter material, both pebbles from the Middle Bunter and quartz grains from the sandstones. Next perhaps in number are erratics from the coalfields and from the Wrekin area. North Welsh rocks are often common, many coming from the Berwyns and the Denbighshire Silurian country. Large boulders of Arenig (and? Aran) origin are common in the district stretching from Walsall through Birmingham and Harborne, and over the Lickeys and Frankley to Bromsgrove. North Welsh material is therefore the most striking of the common fartravelled erratics, and for this reason it is appropriate to term these deposits the Welsh Drifts. To them, however, an Irish Sea Glacier contributed Scottish and Lake District erratics on an exiguous scale. We may perhaps infer from the distribution of the latter that they belong to a later stage in the glaciation than that which was responsible for the more southerly Welsh Drifts, these being devoid of the northern elements. It is important to realize that various lines of evidence point to the fact that it was not the Main Irish Sea Glacier, but an earlier one that introduced these few boulders.

Owing to its position between the spheres of influence of the Irish Sea and the Great Eastern glaciers, this central area with predominantly Welsh drifts offers borderline cases where it is difficult to decide to which glaciation a particular deposit belongs. The Kingswinford Esker described by Boulton, and the gravels with many northern boulders at Maney near Sutton Coldfield, provide two examples where it is a question of distinguish. ing between a Main Irish Sea and a Welsh origin; whereas the drifts of the Ridgeway in East 
Worcestershire seem to be compounded of Welsh and Eastern elements.

Over much of that part of the WarwickshireStaffordshire Plateau which is drained by the upper waters of the Tame, Cole and Blythe, the mantle of drift is comparatively intact, and frequently forms the valley floors; but on the Severn-Avon side of the watershed of England it becomes very ragged, projecting outwards as promontories or forming outliers on the highest hills. This is so far a rule that one is forced to view the capping as remnants of a more or less continuous sheet which once stretched far into the vales of Severn and Avon. Here it has in most places been completely destroyed. Evidence of its presence must be sought for on the hill-tops and not in the valleys, all of which in their present state are younger than the glaciation.

It is, I think, fair to conclude that the ice sheets at their maxima occupied the vales, and that these were far shallower then than now. This hypothesis sounds very speculative, but there are some remarkable pieces of evidence in its favour*.

\section{The River Terraces as Evidence OF THE STAGES IN THE EROSION}

If we are right in claiming a former far wider distribution of the drifts than the areas where they now occur in force, the river valleys should provide a great deal of evidence concerning the way in which their destruction has been brought about. In the present case this is certainly so ; for we have in the Severn and its tributaries a wonderfully developed system of river terraces and of deposits that originated under the rigorous conditions of glacial climates, the so-called taele gravels and melt-water flood gravels.

The farther we go from the plateau and from the drift-covered ground on its north-west and eastern sides the greater the number of high-level terraces. In some cases the geographical distribution and the lithological composition enable us to relate a terrace to a particular set of glacial

* The evidence is discussed in the printed address. deposits. These points are brought out by the accompanying table.

\begin{tabular}{|c|c|c|c|c|c|}
\hline \multirow{2}{*}{ Severn } & \multirow{2}{*}{ Avon* } & \multirow{2}{*}{$\begin{array}{l}\text { Height at } \\
\text { Mouth of } \\
\text { Severn } \dagger\end{array}$} & \multicolumn{2}{|c|}{ Upstream Limit } & \multirow{2}{*}{$\begin{array}{l}\text { Compo- } \\
\text { sition }\end{array}$} \\
\hline & & & Severn & Avon & \\
\hline Woolridge & - & $?$ about 200 & Tewkesbury & - & $B, ? W, M * *$ \\
\hline $\begin{array}{c}\text { Bushley } \\
\text { Green }\end{array}$ & No. 5 & 110/75 0.D. & Tewkesbury & Stratford & $\begin{array}{c}\text { a few } b^{\prime} \\
\text { do. }\end{array}$ \\
\hline $\begin{array}{l}\text { Green } \\
\text { Kidder- } \\
\text { minster }\end{array}$ & No. 4 & 65/35 O.D. & $\begin{array}{l}\text { Bewdley } \\
\text { (goes up } \\
\text { Stour) }\end{array}$ & $\begin{array}{c}\text { Stone- } \\
\text { leigh near } \\
\text { Kenil- } \\
\text { worth }\end{array}$ & do. \\
\hline Main & $\begin{array}{l}\text { Nos. } 2 \\
\& ? 3\end{array}$ & $35 ? / 15 ?$ O.D. & $\begin{array}{l}\text { Coalport } \\
\text { (goes up } \\
\text { Worfe) }\end{array}$ & $\begin{array}{c}\text { Church } \\
\text { Lawford } \\
\text { near } \\
\text { Rugby }\end{array}$ & do. and $S$ \\
\hline Worcester & ? No. 1 & $?-25$ O.D. & Shrewsbury & ? & do., do. \\
\hline
\end{tabular}

* Miss Tomlinson's nomenclature. † Height of top/height of base. ${ }^{* *} B$, Bunter Pebbles; $W$, Welsh; $F$, Flints; $M$, Malvernian ; $S$, Scottish and Lake District.

I have elsewhere discussed the extremely ambiguous evidence bearing on the question whether there was an interglacial episode between the time of the Main and Worcester Terraces, without being able to obtain an assured answer. On the other hand, the fauna of Avon No. 4 is a warm climate one, which makes it probable that both it and its correlative, the Kidderminster Terrace, are interglacial. The position of Avon No. 4 Terrace below Avon No. 5 which connects with the Great Eastern glaciation, and above the terraces, Avon No. 2 and ? No. 3, which correlate with the Main Terrace of the Severn and so with the Irish Sea glaciation, forces us to conclude that these two glaciations were not contemporaneous.

Various lines of evidence converge, therefore, towards the following conclusion: that the Bushley Green-Avon No. 5 Terrace and the still higher Woolridge Terrace are to be correlated with the 'Older Drifts'; that the Main, the Worcester, and Avon No. 2, and possibly Avon No. 3, Terraces, belong to the 'Newer Drifts' ; and that the Kidderminster-Avon No. 4 Terrace records the intervening 'Great Interglacial.' The question whether the older drifts of the Midlands bridge more than one glacial epoch is dealt with in the sequel.

[To be continued.]

\section{Mechanism of the Photographic Process}

A GENERAL discussion on "The Mode of
Section A of the British Association meeting
at Nottingham, was opened by three speakers,
who treated the problem of photography from
three different points of view. Mr. E. R. Davies
drew a picture of the action of light on photo-
graphic materials mainly from physical evidence.
Dr. S. O. Rawling gave an account of the action and theory of development. Prof. N. F. Mott described a theory of light action and latent image formation which was developed on a wavemechanical basis and which provides an explanation for many hitherto puzzling facts and a useful working hypothesis.

The sensitive layer of any piece of photographic material consists of a thin film of gelatin in which is embedded an enormous number of minute 